\title{
Correlation of Serum IgG Concentration in Foals and Refractometry Index of the Dam's Pre- and Post-Parturient Colostrums: An Assessment for Failure of Passive Transfer in Foals
}

\author{
Kenji KOROSUE ${ }^{1)^{*}}$, Harutaka MURASE ${ }^{1)}$, Fumio SATO ${ }^{1)}$, Mutsuki ISHIMARU ${ }^{1)}$, Yasumitsu KOTOYORI ${ }^{2)}$ and \\ Yasuo NAMBO ${ }^{1)}$ \\ 1)Hidaka Training and Research Center, Japan Racing Association, 535-13 Aza-Nishicha, Urakawa-cho, Urakawa-gun, Hokkaido \\ 057-0171, Japan \\ 2) Equine Research Institute, Japan Racing Association, 321-4 Tokami-cho, Utsunomiya, Tochigi 320-0856, Japan
}

(Received 21 October 2011/Accepted 25 May 2012/Published online in J-STAGE 8 June 2012)

ABSTRACT. The object of this study was to evaluate the usefulness of measuring the differences in the values of the serum total protein (DVSTP) concentration of foals and the refractometry index (DVRI) of the milk of dams before and after nursing of the colostrum for assessing failure of passive transfer (FPT) in foals. Serum samples from 31 foals were collected before the first nursing and other 1 to 6 times between 4 and $24 \mathrm{hr}$ after birth. Paired colostrum and milk samples were collected from 14 of their dams at the same time. Serum samples were analyzed for IgG concentration using a single radial immunodiffusion (SRID) test (98 samples) and total protein concentration using a temperature-compensating refractometer (98 samples). Colostrum and milk samples were analyzed for refractometry index (RI) using a Brix refractometer (71 samples). DVSTP concentration and DVRI were significantly correlated with serum IgG concentration. The negative predictive values (NPVs) of DVSTP concentration for detecting serum IgG concentrations $<400 \mathrm{mg} / \mathrm{d} l$ and $<800 \mathrm{mg} / \mathrm{d} l \mathrm{were} 98.2 \%$ and $91.3 \%$ when the cutoff value is set to $0.4 \mathrm{mg} / \mathrm{d} l$ and $0.8 \mathrm{mg} / \mathrm{d} l$, respectively. Furthermore, the NPVs of DVRI for detecting serum IgG concentrations $<400 \mathrm{mg} / \mathrm{d} l$ and $<800 \mathrm{mg} / \mathrm{d} l$ were $97.3 \%$ and $96.3 \%$ when the cutoff value is set to $6 \%$ and $10 \%$, respectively. The results suggest that measurement of DVRI is useful in assessing FPT as an initial "stall-side" screening test, because it is easy, inexpensive to perform and allows for rapid interpretation.

KEY WORDS: failure of passive transfer, foal, $\operatorname{IgG}$, refractometry index, serum total protein.

doi: 10.1292/jvms.11-0470; J. Vet. Med. Sci. 74(11): 1387-1395, 2012

Foals have low concentrations of circulating immunoglobulins at birth, because the diffuse epitheliochorial placenta does not allow antibody transfer during pregnancy $[16,19,30,43]$. Foals are entirely dependent on maternal immunoglobulins (primarily IgG) absorbed through ingestion of mare's colostrum in the first $24 \mathrm{hr}$ of life. Successful absorption of immunoglobulins prevents systemic infection during the lag time between exposure to pathogens and development of protective immune response [19, 20]. Transfer of maternal antibodies is critical for the well-being of foals. Failure of passive transfer (FPT) significantly increases the risk of infections and death $[10,31,32]$. A foal greater than $24 \mathrm{hr}$ of age is considered to have FPT, if the serum $\mathrm{IgG}$ concentration is less than $400 \mathrm{mg} / \mathrm{d} l$. A serum concentration of 400 to $800 \mathrm{mg} / \mathrm{d} l$ over $24 \mathrm{hr}$ after birth is considered partial FPT $[16,31]$, and a serum concentration greater than $800 \mathrm{mg} / \mathrm{d} l$ is considered adequate for protection [16, 25], although many normal foals have much higher concentrations [31]. The incidence of FPT in foals ranges from 3-24\%, and that of partial FPT ranges from $14-31 \%[2,24,27,29,31$,

\footnotetext{
*Correspondence to: Korosue, K., Hidaka Training and Research Center, Japan Racing Association, 535-13 Aza-Nishicha, Urakawa-cho, Urakawa-gun, Hokkaido 057-0171, Japan.

e-mail: Kenji_Korosue@jra.go.jp

(C)2012 The Japanese Society of Veterinary Science
}

\section{5, 37, 44].}

Early testing for serum $\mathrm{IgG}$ concentration in newborn foals can identify potential cases of FPT. Several screening tests have been developed over the years for evaluating the IgG concentration in foals. The single radial immunodiffusion (SRID) test is considered to be the most accurate test for quantitative measurement of IgG concentration in foals [41]. However, results of SRID test are generally not available for $24 \mathrm{hr}$. The $24-\mathrm{hr}$ delay in obtaining test results decreases the usefulness of this test for routine use on a breeding farm, in a field situation or at a veterinary clinic because rapid results are required for therapeutic intervention in FPT cases in foals [1].

Several rapid tests for practical use have been used to estimate IgG concentrations in foals, including the glutaraldehyde coagulation test $[5,9]$, zinc sulfate turbidity test [4, $41]$, latex agglutination test [22, 47], enzyme immunoassay $[6,38]$, turbidimetric immunoassay $[4,11]$ and measurement of serum total protein (STP) concentration [12, 41]. Many of these tests are now commercially available as kits for use on a breeding farm or at a veterinary clinic. One of the most rapid and inexpensive tests is measurement of the STP concentration by refractometry. The major advantage of this test is that it can be performed without having to send a sample to a specialized laboratory. This means this test may be routinely used on a breeding farm or in a field situation, because rapid results are required for determin- 
ing the necessity of therapeutic intervention in FPT cases in foals. However, several reports have indicated that this test is an unreliable indicator of FPT in foals $[12,34,41]$ because unlike in calves, there is a wide range of STP concentrations in newborn foals $[41,45]$.

The most common risk factor for the development of FPT is considered to be poor colostrum quality of the dam (i.e., $\mathrm{IgG}$ concentration of $<3,000 \mathrm{mg} / \mathrm{d} l$ ) $[28,29,31,35,46]$. Therefore, a logical first step in the prevention of FPT is to determine colostrum quality in the immediate postpartum period before the foal's first nurse. Several reports have indicated that the serum IgG concentration in a newborn foal correlates well with the $\operatorname{IgG}$ concentration in its dam's colostrum [13, 24, 26, 28, 35]. Common qualitative techniques used to assess colostrum quality include the colostrometer [28] and Brix (or sugar) refractometer [7, 8]. The Brix refractometer is a more precise, more repeatable and easier to perform in a field assessment of IgG concentration in colostrum compared with the colostrometer [8]. Furthermore, there is a report that Brix refractometer evaluation of equine colostrum quality has been shown to be highly correlated with foal plasma IgG concentrations $(\mathrm{r}=0.85)$ as measured by the SRID test [8]. Therefore, the Brix refractometer has been the best method to assess equine colostrum quality "stallside". However, one report has indicated that foals that fail to nurse due to neonatal weakness or delayed development of the nursing reflex have low IgG concentrations despite adequate Brix refractometer readings of colostrum [7].

We hypothesized that assessment of the colostrum refractometry index (RI) by Brix refractometer and measurement of the foal STP concentration by temperature-compensating refractometry would be more reliable methods as an indicator of a foal's FPT if the differences in the values of refractometry index (DVRI) and of STP (DVSTP) before and after nursing colostrum could be measured. The objective of the study reported here was to determine the correlation between these methods and foal serum IgG concentrations by the SRID test. An additional objective was to determine the usefulness of these methods as an indicator of a foal's FPT in a natural setting.

\section{MATERIALS AND METHODS}

Animals: Thirty-one newborn thoroughbred foals and their dams were employed for this study during 2007-2010 at the Hidaka Training and Research Center in Hokkaido, Japan. All horses were privately owned by the research center. All mares were turned out to pasture between 0800 and $1500 \mathrm{hr}$ and stabled individually in box stalls overnight. The mares were observed for foaling throughout their stay in the stalls by use of video monitoring. This study was approved by the Animal Care and Use Committee at Hidaka Training and Research Center.

Serum and colostrum samples: Serum samples from 23 foals were collected before the first nursing and once again between 12 and $24 \mathrm{hr}$ after birth. Paired colostrum and milk samples were also collected from 6 of their dams at the same time. In addition, serum samples from other 8 foals were col- lected before the first nursing and other 3 to 12 times between 1 and $24 \mathrm{hr}$ after birth. The samples from 6 of these foals were collected before the first nursing, at hourly intervals from 2 to $12 \mathrm{hr}$ after birth and at $24 \mathrm{hr}$ after birth, the samples from one foal were collected before the first nursing and at 4, 6, 10, 12 and $24 \mathrm{hr}$ after birth, and the samples from one foal were collected before the first nursing and at 4, 8 and 12 $\mathrm{hr}$ after birth. Paired colostrum and milk samples were also collected from all their dams at the same time.

In the case of 23 foals in which a total of 2 blood samples were taken, blood samplings were performed by venipuncture using a 21 G x 11/2"needle (NN-2138R, Terumo, Tokyo, Japan) both times. On the other hand, in the case of other 8 foals in which a total of more than 4 blood samples were taken, only the first blood sampling prior to the first nursing was performed by venipuncture using a $21 \mathrm{G}$ x 11/2"needle (NN-2138R, Terumo, Tokyo, Japan), and subsequently, all blood samplings were performed using a $20 \mathrm{G}$ x 2" polyethylene sterile IV catheter (Surflo IV Catheter SR-OT 2051C, Terumo, Tokyo, Japan), which was inserted into the left jugular vein and secured with tape. The site of catheter insertion was clipped and covered with an anesthetizing gel to minimize the response to the initial puncturing of the skin. Five milliliters of blood was collected using a syringe. The blood sample was transferred to a plane $10 \mathrm{ml}$ evacuated tube (Venoject II VP-P100K, Terumo, Tokyo, Japan) immediately after blood collection and then centrifuged at 1,700 $\times \mathrm{g}$ for $10 \mathrm{~min}$ to obtain serum. The total volume of blood collected within $24 \mathrm{hr}$ after birth was up to $65 \mathrm{ml}$ in the case of 13 times of collection. Colostrum and milk sampling was performed manually from both mammary glands separately. The udder area and end of the teat were cleaned using gauze dipped in $0.01 \%$ benzalkonium chloride solution to prevent infection before sampling. The first 2 flows of colostrum and milk were not collected, and subsequent flows were collected until the total volume reached approximate $2 \mathrm{ml}$. All serum, colostrum and milk samples were frozen within $3 \mathrm{hr}$ and stored at $-20^{\circ} \mathrm{C}$ until analyzed. Each sample was thawed and analyzed for each test.

Ninety-eight serum samples, comprising of 46 serum samples from 23 foals in which samples were collected before the first nursing and at 12 and $24 \mathrm{hr}$ after birth and 52 serum samples from 8 foals in which samples were collected before the first nursing and at 4, 6, 8, 10, 12 and 24 hr after birth, were used for analyzing the ROC curve of the STP concentration and the relationship between the IgG concentration and STP concentration. Sixty-seven serum samples, comprising of 23 serum samples from 23 foals in which samples were collected at between 12 and $24 \mathrm{hr}$ after birth and 44 serum samples from 8 foals in which samples were collected at 4, 6, 8, 10, 12 and $24 \mathrm{hr}$ after birth, were used for analyzing the ROC curve of the DVSTP concentration and the relationship between the $\operatorname{IgG}$ concentration and DVSTP concentration. Seventy-one colostrum and milk samples, comprising of 12 samples from 6 dams in which samples were collected before the first nursing and at $12 \mathrm{hr}$ after birth and 59 samples from 8 dams in which samples were collected before the first nursing and at 2, 4, 6, 8, 10, 12 
and $24 \mathrm{hr}$ after birth, were used for analyzing the ROC curve of colostrum/milk RI and the relationship between the IgG concentration of their foal and colostrum/milk RI. Fourteen colostrum samples from 14 dams were collected before the first nursing. Furthermore, fourteen serum samples from their foals were collected between 12 to $24 \mathrm{hr}$ after birth. These samples were used for analyzing the relationship between colostrum RI before the first nursing and serum IgG concentration of their foal collected between 12 to $24 \mathrm{hr}$ after birth. Fifty milk samples, comprising of 6 milk samples from 6 dams in which samples were collected at $12 \mathrm{hr}$ after birth and 44 milk samples from 8 dams in which samples were collected at 4, 6, 8, 10, 12 and $24 \mathrm{hr}$ after birth, were used for analyzing the ROC curve of colostrum/milk DVRI and the relationship between the IgG concentration of their foal and colostrum/milk DVRI. Seventy-eight serum and colostrum/ milk samples from 6 mares and their foals in which samples were collected before the first nursing, at hourly intervals from 2 to $12 \mathrm{hr}$ after birth and at $24 \mathrm{hr}$ after birth were used for observing the hourly changes in serum IgG concentration, STP concentration, DVSTP concentration, colostrum/ milk IgG concentration, colostrum/milk RI and colostrum/ milk DVRI.

Serum IgG measurement: Serum IgG concentration was determined using a commercially available SRID kit (Equine IgG SRID, Ecos Institute Co., Ltd., Miyagi, Japan), according to the manufacturer's instructions. The serum sample was diluted 1:21 with saline. The diluted sample $(5 \mu l)$ was allowed to diffuse for approximately $72 \mathrm{hr}$ in a humid chamber from 2-mm-diameter wells punched in the agar layers. Antiserum specific for the IgG to be measured was incorporated into the agar layers. Calibration curves were prepared using precipitation ring diameters of $50 \mathrm{mg} /$ $\mathrm{d} l$ and $200 \mathrm{mg} / \mathrm{d} l$ as the known standards. There is a linear relationship between the diameter of the ring and the logarithm of the antigen concentration. The concentration of IgG could be obtained by measuring the diameter of each sample precipitation ring. The values were then multiplied by 21 to obtain the IgG concentration of the original serum sample.

STP measurement: STP concentration was determined using a temperature-compensating refractometer (MASTER-SUR/J $\alpha$, Atago Co., Ltd., Tokyo, Japan), according to the manufacturer's instructions. The serum sample (approximately $300 \mu l$ ) was placed on the glass prism of the refractometer and covered with a glass coverslip. The STP concentration was read by looking through the eyepiece while in front of light source.

Colostrum and milk $\operatorname{IgG}$ measurement: Colostrum and milk IgG concentrations of 78 samples from 6 mares, in which samples were collected before the first nursing, at hourly intervals from 2 to $12 \mathrm{hr}$ and at $24 \mathrm{hr}$ after birth, were measured by the SRID test in the same manner as the foal serum $\mathrm{IgG}$ concentrations were measured. The samples were diluted, and the dilutions ranged from 1:11 to 1:61 depending on their expected IgG concentration based on collection time.

RI measurement: The RIs of colostrum and milk samples were determined using a Brix refractometer (PAL-1 Brix refractometer, Atago Co., Ltd., Tokyo, Japan), according to the manufacturer's instructions. Calibration of the Brix refractometer was performed following the steps in the instruction manual prior to measurement. The colostrum $/ \mathrm{milk}$ samples (approximately $300 \mu l$ ) were placed on the prism surface of the Brix refractometer. The RI of the colostrum sample was directly recorded from the digital display. Colostrum and milk samples were collected from both mammary glands separately. The RIs of mammary colostrum and milk samples from both mammary glands were measured. The average RI from both mammary glands was employed as the true RI.

Statistical analysis: The IgG concentrations measured by the SRID test were used as the reference standard to which both assay results were compared. Analyses of relationships were performed as follows: 1) between the serum IgG concentration and STP concentration including the samples before the first nursing; 2) between the serum IgG concentration and the corresponding DVSTP concentration; 3 ) between the serum IgG concentration and the corresponding colostrum/ milk RI; 4) between the serum IgG concentration and the corresponding colostrum/milk DVRI; and 5) between the serum IgG concentration 12-24 hr after birth and the RI of colostrum before the first nursing. Linear regression analysis and Pearson's coefficients of correlation were used to assess each correlation.

Samples were classified on the basis of results of the serum IgG concentrations by the SRID test. A positive test result, which is considered to be a state of partial FPT or FPT, was defined as a serum IgG concentration $<400 \mathrm{mg} / \mathrm{d} l$ and $<800$ $\mathrm{mg} / \mathrm{d} l$, respectively. A negative result, which is considered to be not a state of partial FPT or FPT, was defined as a serum IgG concentration $\geq 400 \mathrm{mg} / \mathrm{d} l$ and $\geq 800 \mathrm{mg} / \mathrm{d} l$, respectively. The sensitivity was defined as the probability of partial FPT or FPT based on each test. The specificity was defined as the probability of no partial FPT or FPT based on each test. Furthermore, the positive predictive value (PPV) was defined as the probability of partial FPT or FPT in the foals that had a positive condition as indicated by each test. The negative predictive value (NPV) was defined as the probability of no partial FPT or FPT in the foals that had a negative condition as indicated by each test. Sensitivity, specificity and PPV/NPV of each assay were calculated for the detection of serum $\operatorname{IgG}$ concentrations at breakpoints of $<400 \mathrm{mg} / \mathrm{d} l$ and $<800 \mathrm{mg} / \mathrm{d} l$.

The cutoff value, which correspond to the break point of $<400 \mathrm{mg} / \mathrm{d} l$ and $<800 \mathrm{mg} / \mathrm{d} l$ of serum $\mathrm{IgG}$ concentrations, sensitivity, specificity and PPV/NPV for each test, was assessed by use of receiver operating characteristics (ROC) curve analysis with the ROCKIT $0.9 \beta$ Beta version software (Kurt Rossmann Laboratories for Radiologic Image Research) [33]. In general, ROC curves can be used to identify the optimal cutoff value between positive conditions and negative conditions for diagnostic tests, with each value on an ROC curve representing a trade-off between sensitivity and specificity. Tests that combine high sensitivity with high specificity are best at discriminating between positive conditions and negative conditions. The area under the curve 


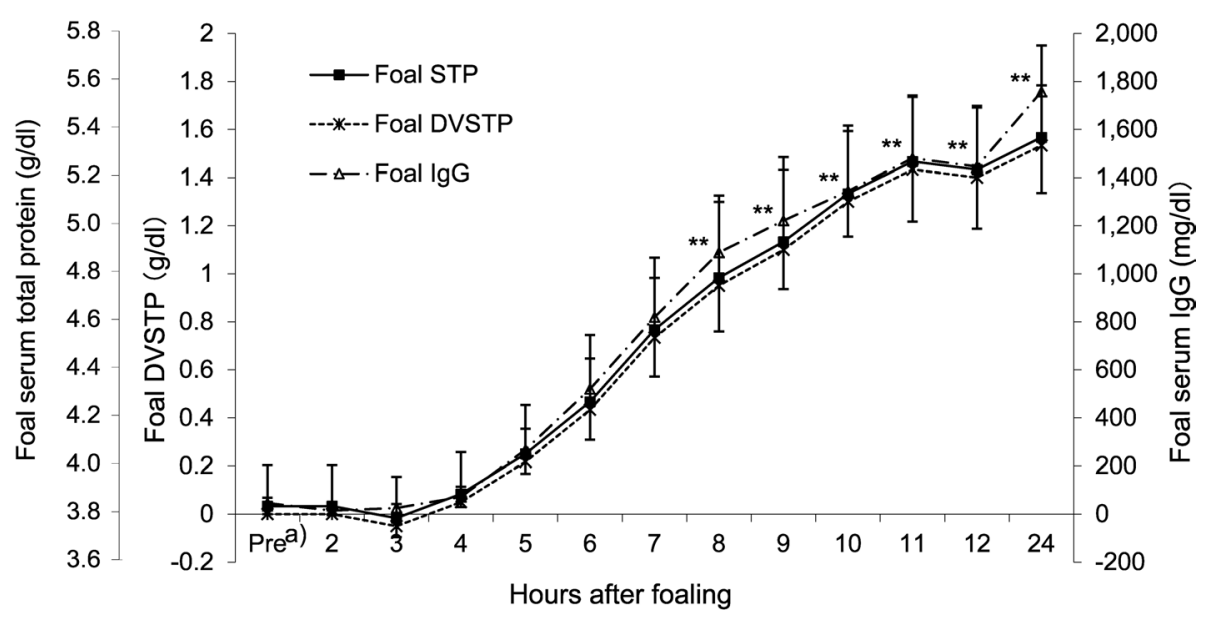

Fig. 1. Changes in foal serum IgG, foal STP and foal DVSTP from before suckling to $24 \mathrm{hr}$ after birth. Results represent the mean and SEM. a) Pre: before the first nursing. Asterisks indicate significant differences in foal serum IgG compared with the time before the first nursing $(* * P<0.01)$.

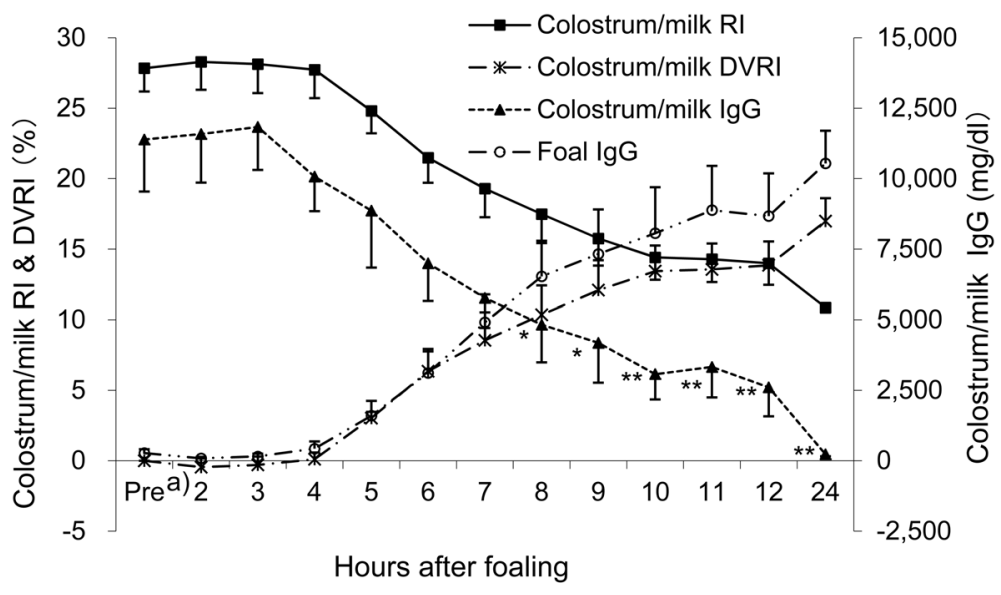

Fig. 2. Changes in foal serum IgG, colostrum/milk IgG, colostrum/milk RI and colostrum/milk DVRI from before suckling to $24 \mathrm{hr}$ after birth. Results represent the mean and SEM. a) Pre: before the first nursing. Asterisks indicate significant differences in colostrum/milk IgG compared with the time before the first nursing $(* P<0.05 ; * * P<0.01)$.

(AUC) of an ROC curve quantifies the overall ability of the test to discriminate between positive conditions and negative conditions. Reliability is expressed as the AUC of the ROC curve. An evaluation value is set to a maximum of 1 and a minimum of 0.5 . Reliability is high, and a value exceeding 0.8 is considered excellent $[14,21]$. On the basis of measures of minimal distance to the upper left corner of the ROC curve, an STP concentration of $4.6 \mathrm{~g} / \mathrm{d} l$, DVSTP concentration of $0.4 \mathrm{~g} / \mathrm{d} l$, RI of $21 \%$ and DVRI of $6 \%$ were most suitable as the cutoff values corresponding to the break point of $<400 \mathrm{mg} / \mathrm{d} l$ for the serum IgG concentration, respectively. Similarly, an STP concentration of $4.8 \mathrm{~g} / \mathrm{d} l$, DVSTP concentration of $0.8 \mathrm{~g} / \mathrm{d} l$, RI of $18 \%$ and DVRI of $10 \%$ were most suitable as the cutoff values corresponding to the break point of $<800 \mathrm{mg} / \mathrm{d} l$ for the serum IgG concentration, respectively. Therefore, a positive test status considered to be a state of FPT in each test was defined as an STP concentration $<4.6 \mathrm{~g} /$ $\mathrm{d} l$, DVSTP concentration $<0.4 \mathrm{~g} / \mathrm{d} l, \mathrm{RI}>21 \%$ and $\mathrm{DVRI}<6 \%$, respectively. Similarly, a positive test status considered to be a state of partial FPT in each test was defined as an STP concentration $<4.8 \mathrm{~g} / \mathrm{d} l$, DVSTP concentration $<0.8 \mathrm{~g} / \mathrm{d} l$, $\mathrm{RI}>18 \%$ and $\mathrm{DVRI}<10 \%$, respectively.

A repeated-measures ANOVA followed by Dunnett's test was applied to compare the temporal and hourly changes in the foal serum $\operatorname{IgG}$ concentration and the colostrum $/ \mathrm{milk}$ IgG concentration. Statistical analyses were performed using the JMP v. 5.0.1 software (SAS Institute Japan Inc., Tokyo, Japan) with $P<0.05$ set for significance. 


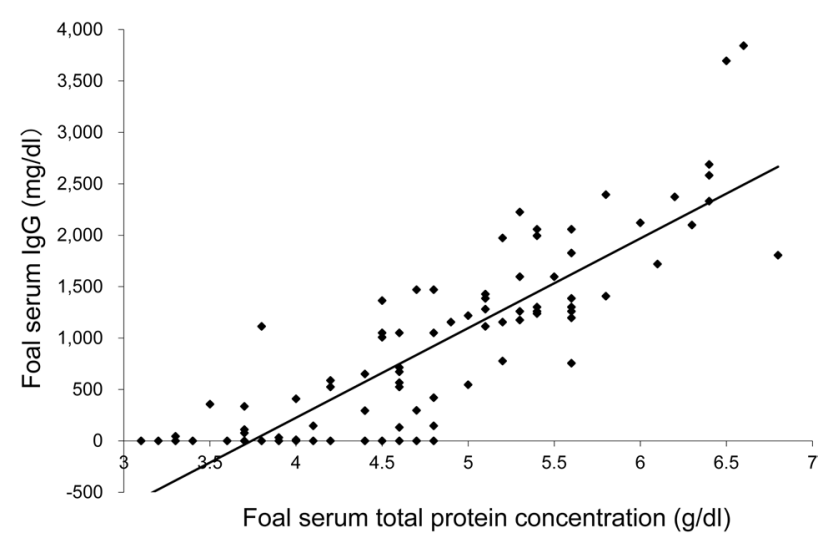

Fig. 3. Correlation between the serum IgG concentration and STP concentration including the samples before the first nursing. Regression line: $\mathrm{Y}=871.78 \mathrm{X}-3261.5(\mathrm{r}=0.86, P<0.0001)$.

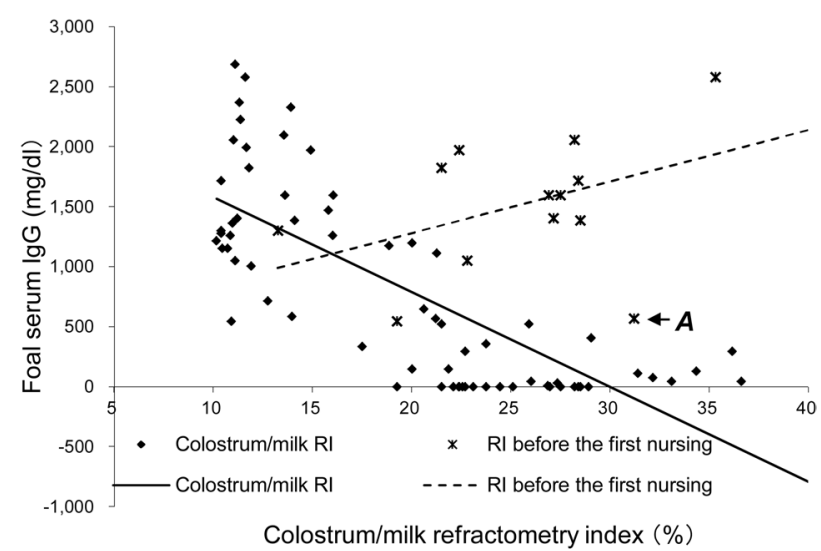

Fig. 5. Correlation between the serum IgG concentration and corresponding colostrum/milk RI including the samples before the first nursing $(\diamond$, regression line: $\mathrm{Y}=-79.089 \mathrm{X}+2370.3, \mathrm{r}=-0.77$, $P<0.0001$ ) and between the serum IgG concentration $12-24 \mathrm{hr}$ after birth and the corresponding RI of colostrum before the first nursing (*, regression line: $\mathrm{Y}=42.915 \mathrm{X}+423.53, \mathrm{r}=0.49, P=0.074)$. See the text for an explanation of $A$.

\section{RESULTS}

Changes in foal serum IgG, foal STP, foal DVSTP, colostrum/milk IgG, colostrum/milk RI and colostrum/milk DVRI: The pattern of change in each measurement value of 6 foals and mares that were sampled at hourly intervals is presented in Figs. 1 and 2. The foal serum IgG concentration had a tendency to increase from $4 \mathrm{hr}$ after birth. The foal serum IgG concentration at $8 \mathrm{hr}$ after birth was significantly different from that before the first nursing $(P<0.01)$. The hourly increment in the foal serum IgG concentration between 6 and $7 \mathrm{hr}$ was the greatest; however, there was no significant difference among the different time points. On the other hand, the colostrum/milk IgG concentration had a tendency to decrease from $4 \mathrm{hr}$ after birth. The colostrum/milk IgG

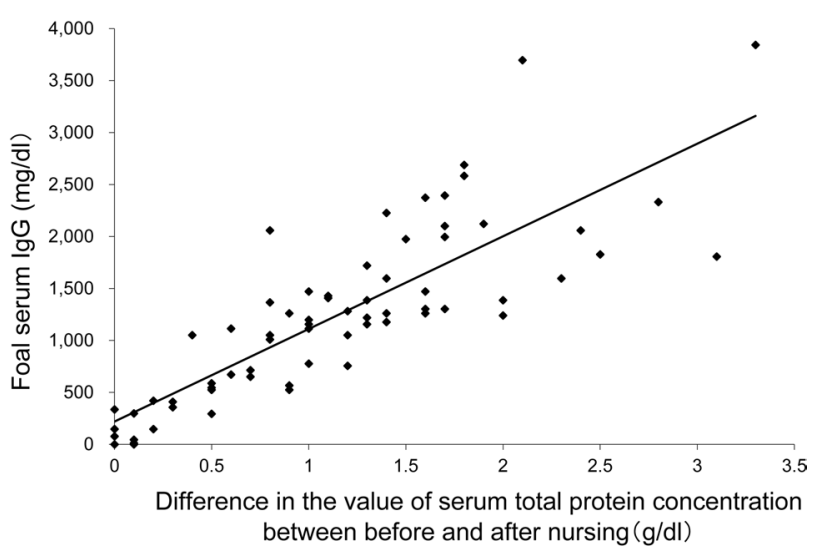

Fig. 4. Correlation between the serum IgG concentration and corresponding DVSTP concentration after and before the first nursing. Regression line: $\mathrm{Y}=891.43 \mathrm{X}-218.85(\mathrm{r}=0.83, P<0.0001)$.

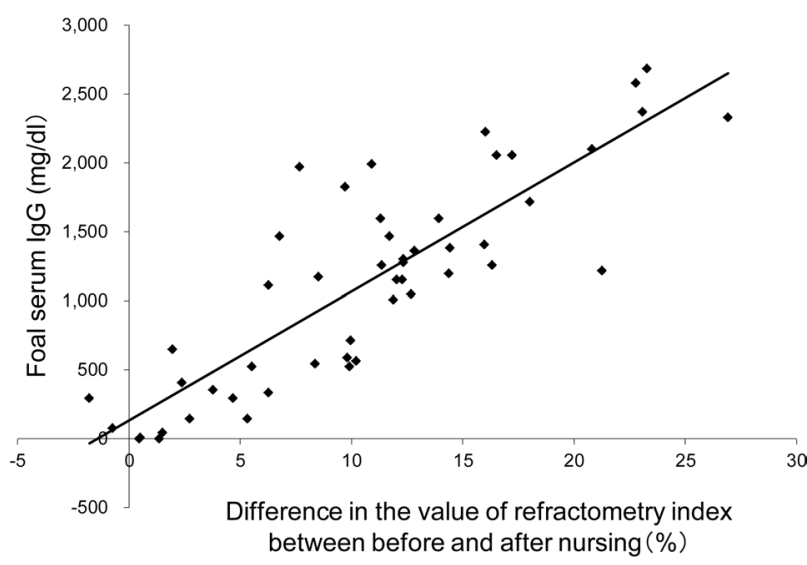

Fig. 6. Correlation between the serum IgG concentration and corresponding DVRI of colostrum before the first nursing and milk at each time point after first nursing. Regression line: $\mathrm{Y}=93.564 \mathrm{X}+$ $135.74(\mathrm{r}=0.85, P<0.0001)$.

concentration at $8 \mathrm{hr}$ after birth was significantly different from that before the first nursing $(P<0.05)$. The hourly decrement of the colostrum/milk IgG concentration between 5 and $6 \mathrm{hr}$ was the greatest; however, there was no significant difference among the different time points.

Relationship between serum IgG concentration and each assay: The STP concentration, DVSTP concentration, and DVRI were significantly correlated with the serum IgG concentration (STP concentration, $\mathrm{r}=0.86, P<0.0001$; DVSTP concentration, $\mathrm{r}=0.83, \quad P<0.0001$; and DVRI, $\mathrm{r}=0.85$, $P<0.0001)$. The RI was significantly negatively correlated with the serum $\operatorname{IgG}$ concentration $(\mathrm{r}=-0.77, P<0.0001)$. The correlations between the serum IgG concentration and corresponding value of the STP concentration, DVSTP concentration, RI and DVRI are presented in Figs. 3, 4, 5 and 6, respectively. On the other hand, no significant correlation was found between the RI of colostrum before the first nursing and the serum IgG concentration 12-24 hr after birth 
Table 1. AUCs of ROC curves, cutoff value, sensitivity, specificity, PPV and NPV of each test

\begin{tabular}{|c|c|c|c|c|c|c|c|c|c|}
\hline \multirow{3}{*}{$\begin{array}{l}\text { Test } \\
\text { Method } \\
\text { (unit) }\end{array}$} & \multirow{3}{*}{$\begin{array}{l}\text { Cutoff value } \\
\text { with serum } \\
\text { IgG } \\
\text { concentration } \\
(\mathrm{mg} / \mathrm{d} l)\end{array}$} & \multicolumn{4}{|c|}{ ROC analysis } & \multirow{3}{*}{$\begin{array}{c}\text { Sensitivity } \\
(\%)\end{array}$} & \multirow{3}{*}{$\begin{array}{l}\text { Specificity } \\
(\%)\end{array}$} & \multirow{3}{*}{$\begin{array}{l}\text { PPV } \\
(\%)\end{array}$} & \multirow{3}{*}{$\begin{array}{l}\text { NPV } \\
(\%)\end{array}$} \\
\hline & & \multicolumn{2}{|c|}{ AUC } & \multicolumn{2}{|c|}{ Cutoff } & & & & \\
\hline & & $\mathrm{AUC} \pm \mathrm{SE}$ & $\begin{array}{c}95 \% \text { Confidence } \\
\text { interval }\end{array}$ & $\begin{array}{c}\text { Optimal cutoff } \\
\text { value }\end{array}$ & $\begin{array}{c}\text { Minimal } \\
\text { distance to left } \\
\text { upper corner }\end{array}$ & & & & \\
\hline \multirow{2}{*}{$\begin{array}{l}\mathrm{STP} \\
(\mathrm{g} / \mathrm{d} l)\end{array}$} & $<800$ & $0.94 \pm 0.02$ & $0.88-0.98$ & 4.8 & 0.031 & 88.9 & 86.4 & 88.9 & 86.4 \\
\hline & $<400$ & $0.95 \pm 0.02$ & $0.89-0.98$ & 4.6 & 0.048 & 83.3 & 85.7 & 81.4 & 87.3 \\
\hline \multirow{2}{*}{$\begin{array}{c}\text { DVSTP } \\
(\mathrm{g} / \mathrm{d} l)\end{array}$} & $<800$ & $0.95 \pm 0.03$ & $0.87-0.98$ & 0.8 & 0.032 & 82.6 & 95.5 & 90.5 & 91.3 \\
\hline & $<400$ & $0.99 \pm 0.01$ & $0.93-0.99$ & 0.4 & 0.010 & 90.9 & 96.4 & 83.3 & 98.2 \\
\hline \multirow{2}{*}{$\begin{array}{l}\text { RI } \\
(\%)\end{array}$} & $<800$ & $0.96 \pm 0.23$ & $0.89-0.99$ & 18 & 0.019 & 90.0 & 90.3 & 92.3 & 87.5 \\
\hline & $<400$ & $0.96 \pm 0.24$ & $0.89-0.99$ & 21 & 0.025 & 90.6 & 87.2 & 85.3 & 91.9 \\
\hline \multirow{2}{*}{$\begin{array}{l}\text { DVRI } \\
(\%)\end{array}$} & $<800$ & $0.96 \pm 0.02$ & $0.88-0.99$ & 10 & 0.029 & 94.7 & 83.9 & 78.3 & 96.3 \\
\hline & $<400$ & $0.98 \pm 0.02$ & $0.90-0.99$ & 6 & 0.014 & 90.9 & 92.3 & 76.9 & 97.3 \\
\hline
\end{tabular}

STP: serum total protein. DVSTP: differences in the values of serum total protein. RI: refractometry index. DVRI: differences in the values of refractometry index. ROC: receiver operating characteristics. AUC: area under the curve of an ROC curve. PPV: positive predictive value. NPV: negative predictive value.

$(\mathrm{r}=0.49, P=0.074$. Fig. 5). One low serum $\mathrm{IgG}$ result with a high RI of colostrum, labeled $A$ on Fig. 5, was from a weak foal that failed to nurse colostrum until $10 \mathrm{hr}$ after birth.

ROC analysis: The AUCs of the ROC curves and the optimal cutoff values, based on the ROC analysis of each assay, are shown in Table 1 . In detecting serum IgG concentrations $<400 \mathrm{mg} / \mathrm{d} l$ and $<800 \mathrm{mg} / \mathrm{d} l$, the AUCs of the STP concentration, DVSTP concentration, RI and DVRI exceeded 0.9, which was considered substantially accurate.

Sensitivity, specificity, PPV and NPV: The optimal cutoff value of each assay was selected by analysis of the AUC of the ROC curve. Sensitivity, specificity, PPV and NPV at the optimal cutoff value are shown in Table 1. The NPV of the DVSTP concentration for detecting serum IgG concentrations $<400 \mathrm{mg} / \mathrm{d} l$ (cutoff value of $0.4 \mathrm{~g} / \mathrm{d} l$ ) was $98.2 \%$, and that for $<800 \mathrm{mg} / \mathrm{d} l$ (cutoff value of $0.8 \mathrm{~g} / \mathrm{d} l$ ) was $91.3 \%$, which was better than the NPV of the STP concentration, which was $87.3 \%$ at $<400 \mathrm{mg} / \mathrm{d} l$ (cutoff value of $4.6 \mathrm{~g} / \mathrm{d} l$ ) and $86.4 \%$ at $<800 \mathrm{mg} / \mathrm{d} l$ (cutoff value of $4.8 \mathrm{~g} / \mathrm{d} l$ ). The NPV of the DVRI for detecting serum IgG concentrations $<400 \mathrm{mg} /$ $\mathrm{d} l$ (cutoff value of $6 \%$ ) was $97.3 \%$, and that for $<800 \mathrm{mg} /$ $\mathrm{d} l$ (cutoff value of $10 \%$ ) was $96.3 \%$, which was better than the NPV of the RI, which was $91.9 \%$ at $<400 \mathrm{mg} / \mathrm{d} l$ (cutoff value of $21 \%$ ) and $87.5 \%$ at $<800 \mathrm{mg} / \mathrm{d} l$ (cutoff value of $18 \%)$.

\section{DISCUSSION}

This study is the first to demonstrate the relationship between the DVSTP concentration or DVRI and serum IgG concentrations. The results of this study suggest that the DVSTP concentration and DVRI are useful methods for earlier and easier assessment of FPT in foals.

It has been suggested that FPT may be positively correlated with bacterial sepsis in foals $[9,10,15,31,39,40]$. These results indicate that early diagnosis and treatment of FPT are important. It has been recommended that a newborn foal's serum should be tested as early as 8 to $12 \mathrm{hr}$ after birth to assess whether adequate colostral IgG has been absorbed because a foal's ability to absorb colostral IgG is greatest during the first 6 to $8 \mathrm{hr}$ and optimal absorption of colostral IgG occurs by $12 \mathrm{hr}$ after birth [1]. The results of this study also demonstrated similar findings showing that a foal's ability to absorb colostral $\mathrm{IgG}$ is greatest during the first 6 to $8 \mathrm{hr}$. Thus, absorption of antibodies in the small intestine by specialized enterocytes, which non-selectively absorb the colostral immunoglobulins by pinocytosis and transfer them into the foal's blood, is greatest during the first 6 to $8 \mathrm{hr}$ after birth. Absorption of immunoglobulins ceases by 24 to $36 \mathrm{hr}$ after birth because the specialized enterocytes have been replaced by epithelial cells that are incapable of pinocytosis (i.e., gut closure) $[16,17,19,23,36]$. If a foal's IgG concentrations are low within $12 \mathrm{hr}$ after birth, the foal could be given supplemental colostrum within $24 \mathrm{hr}$ but preferably within $12 \mathrm{hr}$, because a foal's ability to absorb colostral IgG is significantly diminished by 24 to $36 \mathrm{hr}$ after birth $[16,17,19,23,36]$. This means that early diagnosis and treatment of FPT are useful to save the expense of a plasma transfusion. Measuring a foal's serum IgG concentration is useful as an indicator of FPT in foals. Although the optimal concentration of $\mathrm{IgG}$ is uncertain, an IgG concentration of 400 to $800 \mathrm{mg} / \mathrm{d} l$ is commonly recommended, and intravenous administration of plasma is required in foals with an $\mathrm{IgG}$ concentration $<400 \mathrm{mg} / \mathrm{d} l$ at $24 \mathrm{hr}$ after birth [42]. However, several studies suggest that a foal with an $\operatorname{IgG}$ concentration of $<800 \mathrm{mg} / \mathrm{d} l$ at 18 to $24 \mathrm{hr}$ after birth should be administered intravenous plasma because a concentration of at least $800 \mathrm{mg} / \mathrm{d} l \mathrm{IgG}$ provides a significantly higher survival rate and lower perinatal infection rate $[3,39]$. Based on the clinical relevance, the definition of cutoff concentrations in this study was calculated for threshold values of 400 and $800 \mathrm{mg} / \mathrm{d} l$.

Early detection of FPT has been useful to reduce the risk of disease in foals. When an early screening test for the detection of FPT is performed, a high sensitivity test must be selected. This ensures a high NPV test, hence identifying most foals with FPT. Furthermore, an early screening test needs to be easy, rapid, inexpensive to perform and accurate. 
Refractometry was chosen as an early screening test for measuring STP concentration in this study, because it can be rapid, inexpensive and convenient and does not require sending of samples to a specialized laboratory. However, the results of several reports have indicated that this test is an unreliable indicator of FPT in foals [12, 34, 41]. It is considered that the cause of these results is the wide range of STP concentrations in newborn foals before nursing colostrum [41], unlike in calves [45]. This finding is not surprising given that dehydration and variable serum albumin concentrations in hypogammaglobulinemic foals can produce STP concentrations within the reference range for normal foals [25]. Measuring STP is an indirect way to estimate the $\mathrm{IgG}$ concentration and is based on the assumption that low STP after nursing colostrum reflects a failure in transfer of maternal antibodies [18]. On the other hand, several studies have suggested that STP concentrations using a cutoff value of $<4.6$ or $4.7 \mathrm{~g} / \mathrm{d} l$ are likely to indicate FPT and that measurement of the STP concentration might be used as a guide to assess the $\mathrm{IgG}$ concentration if no other test is available or as an adjunctive test $[12,46]$. In this study, the STP concentration was significantly correlated with the serum $\mathrm{IgG}$ concentration $(\mathrm{r}=0.86)$, which confirms the results obtained in a previous study $(\mathrm{r}=0.85)$ [41]. These results indicate that increases in STP in the neonate reflected $\mathrm{IgG}$ concentration. However, in this study as well as a previous study [41], the wide dispersal of data points suggested that serious errors might result if the STP concentration is used to estimate FPT because the STP concentration before nursing varies from 3.1 to $4.8 \mathrm{~g} / \mathrm{d} l$, with an even greater variation in albumin fraction. As can be seen in Fig. 1, some foals had a higher STP concentration before nursing colostrum than some older foals had after nursing colostrum. This suggests that measurement of STP concentration is an unreliable indicator of FPT, especially at low IgG concentrations. To solve the problem of the wide variance in STP concentrations, the DVSTP concentration before and after nursing colostrum was measured. The DVSTP concentration was significantly correlated with the corresponding serum IgG concentration $(r=0.83)$, which showed a similar level of correlation with the STP concentration $(\mathrm{r}=0.86)$. The sensitivity of the DVSTP concentration for detecting a serum IgG concentration $<400$ $\mathrm{mg} / \mathrm{d} l$ (cutoff value of $0.4 \mathrm{~g} / \mathrm{d} l$ ) was $90.9 \%$, and that for $<800$ $\mathrm{mg} / \mathrm{d} l$ (cutoff value of $0.8 \mathrm{~g} / \mathrm{d} l$ ) was $82.6 \%$. Furthermore, the specificity of the DVSTP concentration for detecting serum IgG concentrations $<400 \mathrm{mg} / \mathrm{d} l$ was $96.4 \%$, and that for $<800$ $\mathrm{mg} / \mathrm{d} l$ was $95.5 \%$. These results highlight the fact that the DVSTP concentration before and after nursing colostrum is useful in assessing FPT in foals as a screening test. This method requires collecting blood twice: before nursing and 8 to $12 \mathrm{hr}$ after birth. Minimal equipment is needed for this testing: a needle/syringe, centrifuge and refractometer.

The RI of colostrum/milk was significantly negatively correlated with the serum $\operatorname{IgG}$ concentration $(\mathrm{r}=-0.77)$ in this study. On the other hand, the RI of colostrum was not significantly correlated with the serum IgG concentration $12-24 \mathrm{hr}$ after birth $(\mathrm{r}=0.49)$ in this study, which was lower than the correlation in a previous study $(\mathrm{r}=0.64)$ [7]. This may be the result of differences in parameters between this study $(\mathrm{n}=14)$ and the previous study $(\mathrm{n}=52)$. One low serum IgG result with a high RI of colostrum, labeled $A$ on Fig. 5, was from a weak foal that failed to nurse colostrum until 10 hr after birth. Thus, measurement of the RI of colostrum is useful in assessing FPT in foals as an initial screening test, except in the case of foals that fail to nurse colostrum such as those that are weak or born prematurely. To solve this problem, when it was an unreliable means to assess FPT in a foal that fails to nurse colostrum, the DVRI before and after nursing colostrum was calculated. The DVRI was significantly correlated with the corresponding serum IgG concentration $(\mathrm{r}=0.85)$. The sensitivity of DVRI for detecting serum $\mathrm{IgG}$ concentrations $<400 \mathrm{mg} / \mathrm{d} l$ (cutoff value of $6 \%$ ) was $90.9 \%$, and that for $<800 \mathrm{mg} / \mathrm{d} l$ (cutoff value of $10 \%$ ) was $94.7 \%$. Furthermore, the NPV of DVRI for detecting serum IgG concentrations $<400 \mathrm{mg} / \mathrm{d} l$ was $97.3 \%$, which was the same level as that of the DVSTP concentration $(98.2 \%)$, and that for $<800 \mathrm{mg} / \mathrm{d} l$ was $96.3 \%$, which was higher than that of the DVSTP concentration (91.3\%). In general, if a test has a high NPV, it is suitable for identifying most positive conditions. Therefore, the high NPV of DVRI means that DVRI measurements before and after nursing colostrum are quite useful in assessing FPT in foals as an initial screening test. Furthermore, this test is procedurally easy to perform, allows for rapid interpretation and is more cost-effective than other commercially available test kits, including measurement of the STP concentration by a refractometer. On the other hand, in situations of failure to absorb colostral $\mathrm{IgG}$ in spite of ingesting sufficient colostral $\mathrm{IgG}$, this method may be an unreliable indicator of FPT in foals. Measuring DVRI is an indirect method of estimating the IgG concentration based on previous reports that the RI of colostrum was highly correlated with the $\mathrm{IgG}$ concentration and well correlated with the serum $\mathrm{IgG}$ concentration in foals $[7,8]$. Foals that are slow to suckle because of weakness or sickness are more likely to have a decreased efficiency of IgG absorption. Therefore, when these abnormalities are suspected, other direct tests for estimating the IgG concentration are recommended.

In conclusion, the results of this study clearly demonstrate that measurements of the DVSTP concentration and DVRI before and after nursing colostrum are useful in assessing FPT in foals as a screening test. The former test is effective in assessing a foal with $\mathrm{IgG}$ concentrations $<400 \mathrm{mg} / \mathrm{d} l$ and $<800 \mathrm{mg} / \mathrm{d} l$ when the cutoff value is set to $0.4 \mathrm{~g} / \mathrm{d} l$ and $0.8 \mathrm{~g} / \mathrm{d} l$, respectively. The latter test is effective in assessing a foal with $\mathrm{IgG}$ concentrations $<400 \mathrm{mg} / \mathrm{d} l$ and $<800 \mathrm{mg} / \mathrm{d} l$ when the cutoff value is set to $6 \%$ and $10 \%$, respectively. Both tests are as accurate as other commercially available test kits reported by a previous study [12]. The results particularly suggest that the measurement of DVRI is quite useful in assessing FPT in foals as an initial screening test "stall-side" because it has a relatively high NPV, and of more importance, it is procedurally easier to perform, allows for rapid interpretation and is more cost-effective than any other commercially available test kit. Treatment of foals with FPT can be greatly improved using this easy method, because foals with FPT can be assessed within $12 \mathrm{hr}$ after birth by 
this method and immediate treatment with banked colostrum may be initiated.

ACKNOWLEDGMENT. We express our gratitude to Professor Irwin K. Liu, Department of Population Health and Reproduction, School of Veterinary Medicine, University of California, Davis, for reading the original manuscript and for his valuable suggestions.

\section{REFERENCES}

1. Baird, A. N., Pugh, D. G., Rupp, G. P., Shull, J. W. and Field, R. W. 1987. Detection of immunoglobulin G in the neonate. Equine Vet. Sci. 7: 124-129. [CrossRef]

2. Baldwin, J. L., Cooper, W. L., Vanderwall, D. K. and Erb, R. W. 1989. Immnoglobulin $G$ and early survival of foals: a three year field study. pp. 179-185. In: Proceedings of 35th Annu. Conv. Am. Assoc. Equine Practnr.

3. Baldwin, J. L., Cooper, W. L., Vanderwall, D. K. and Erb, H. N. 1991. Prevalence (treatment days) and severity of illness in hypogammaglobulinemic and normogammaglobulinemic foals. J. Am. Vet. Med. Assoc. 198: 423-428. [Medline]

4. Bauer, J. E. and Brooks, T. P. 1990. Immunoturbidimetric quantification of serum immunoglobulin $\mathrm{G}$ concentration in foals. Am. J. Vet. Res. 51: 1211-1214. [Medline]

5. Beetson, S. A., Hilbert, B. J. and Mills, J. N. 1985. The use of the glutaraldehyde coagulation test for detection of hypogammaglobulinaemia in neonatal foals. Aust. Vet. J. 62: 279-281. [Medline] [CrossRef]

6. Bertone, J. J., Jones, R. L. and Curtis, C. R. 1988. Evaluation of a test kit for determination of serum immunoglobulin $\mathrm{G}$ concentration in foals. J. Vet. Intern. Med. 2: 181-183. [Medline] [CrossRef]

7. Cash, R. S. G. 1999. Colostral quality determined by refractometry. Equine Vet. Educ. 11: 36-38. [CrossRef]

8. Chavatte, P., Cle'ment, F., Cash, R. and Grongnet, J. F. 1998. Field Determination of Colostrum Quality by Using a Novel, Practical Method. pp. 206-209. In: Proceedings of 44th Annu. Conv. Am. Assoc. Equine Practnr.

9. Clabough, D. L., Levine, J. F., Grant, G. L. and Conboy, H. S. 1991. Factors associated with failure of passive transfer of colostral antibodies in Standardbred foals. J. Vet. Intern. Med. 5: 335-340. [Medline] [CrossRef]

10. Cohen, N. D. 1994. Causes of and farm management factors associated with disease and death in foals. J. Am. Vet. Med. Assoc. 204: 1644-1651. [Medline]

11. Davis, R. and Giguere, S. 2005. Evaluation of five commercially available assays and measurement of serum total protein concentration via refractometry for the diagnosis of failure of passive transfer of immunity in foals. J. Am. Vet. Med. Assoc. 227: 1640-1645. [Medline] [CrossRef]

12. Davis, D. G., Schaefer, D. M., Hinchcliff, K. W., Wellman, M. L., Willet, V. E. and Fletcher, J. M. 2005. Measurement of serum IgG in foals by radial immunodiffusion and automated turbidimetric immunoassay. J. Vet. Intern. Med. 19: 93-96. [Medline] [CrossRef]

13. Erhard, M. H., Luft, C., Remler, H. P. and Stangassinger, M. 2001. Assessment of colostral transfer and systemic availability of immunoglobulin $\mathrm{G}$ in new-born foals using a newly developed enzyme-linked immunosorbent assay (ELISA) system. J. Anim. Physiol. Anim. Nutr. (Berl.) 85: 164-173. [Medline] [CrossRef]

14. Greiner, M. 1995. A modified ROC analysis. J. Immunol. Meth- ods 185: 123-132. [Medline] [CrossRef]

15. Haas, S. D., Bristol, F. and Card, C. E. 1996. Risk factors associated with the incidence of foal mortality in an extensively managed mare herd. Can. Vet. J. 37: 91-95. [Medline]

16. Hines, M. T. 2003. Immunodeficiencies of foals. pp. 692-697. In: Current Therapy in Equine Medicine, 5th ed. (Robinson, N.E, ed.), WB Saunders, Philadelphia.

17. Jeffcott, L. B. 1971. Duration of permeability of the intestine to macromolecules in the newly-born foal. Vet. Rec. 88: 340-341. [Medline] [CrossRef]

18. Jeffcott, L. B. 1972. Passive immunity and its transfer with special reference to the horse. Biol. Rev. Camb. Philos. Soc. 47: 439-464. [Medline] [CrossRef]

19. Jeffcott, L. B. 1974. Some practical aspects of the transfer of passive immunity to newborn foals. Equine Vet. J. 6: 109-115. [Medline] [CrossRef]

20. Jeffcott, L. B. 1975. The transfer of passive immunity to the foal and its relation to immune status after birth. J. Reprod. Fertil. Suppl. 727-733. [Medline]

21. Jensen, A. L. 1992. Evaluation of diagnostic tests using. Zentralbl. Veterinarmed. A 39: 656-668. [Medline]

22. Kent, J. E. and Blackmore, D. J. 1985. Measurement of IgG in equine blood by immunoturbidimetry and latex agglutination. Equine Vet. J. 17: 125-129. [Medline] [CrossRef]

23. Knottenbelt, D. C., Holdstock, N. and Madigan, J. E. 2004. The role of colostrum in immunity. pp. 15-18. In: Equine Neonatology, Medicine and Surgery (Knottenbelt, D.C, Holdstock, N. and Madigan, J.E, eds.), WB Saunders, Philadelphia.

24. Kohn, C. W., Knight, D., Hueston, W., Jacobs, R. and Reed, S. M. 1989. Colostral and serum IgG, IgA, and IgM concentrations in Standardbred mares and their foals at parturition. J. Am. Vet. Med. Assoc. 195: 64-68. [Medline]

25. Koterba, A. M., Brewer, B. D. and Tarplee, F. A. 1984. Clinical and clinicopathological characteristics of the septicaemic neonatal foal: review of 38 cases. Equine Vet. J. 16: 376-382. [Medline] [CrossRef]

26. Lavoie, J. P., Spensley, M. S., Smith, B. P. and Mihalyi, J. 1989. Colostral volume and immunoglobulin $\mathrm{G}$ and $\mathrm{M}$ determinations in mares. Am. J. Vet. Res. 50: 466-470. [Medline]

27. LeBlanc, M. M., McLaurin, B. I. and Boswell, R. 1986. Relationships among serum immunoglobulin concentration in foals, colostral specific gravity, and colostral immunoglobulin concentration. J. Am. Vet. Med. Assoc. 189: 57-60. [Medline]

28. LeBlanc, M. M., Hurtgen, J. P. and Lyle, S. 1990. A modified zinc sulfate turbidity test for the detection of immune status in newlyborn foals. Equine Vet. Sci. 10: 36-39. [CrossRef]

29. LeBlanc, M. M., Tran, T., Baldwin, J. L. and Pritchard, E. L. 1992. Factors that influence passive transfer of immunoglobulins in foals. J. Am. Vet. Med. Assoc. 200: 179-183. [Medline]

30. McGuire, T. C. and Crawford, T. B. 1973. Passive immunity in the foal: measurement of immunoglobulin classes and specific antibody. Am. J. Vet. Res. 34: 1299-1303. [Medline]

31. McGuire, T. C., Poppie, M. J. and Banks, K. L. 1975. Hypogammaglobulinemia predisposing to infection in foals. J. Am. Vet. Med. Assoc. 166: 71-75. [Medline]

32. McGuire, T. C., Crawford, T. B., Hallowell, A. L. and Macomber, L. E. 1977. Failure of colostral immunoglobulin transfer as an explanation for most infections and deaths of neonatal foals. J. Am. Vet. Med. Assoc. 170: 1302-1304. [Medline]

33. Metz, C. E. 1986. ROC methodology in radiologic imaging. Invest. Radiol. 21: 720-733. [Medline] [CrossRef]

34. Metzger, N., Hinchcliff, K. W., Hardy, J., Schwarzwald, C. C. and Wittum, T. 2006. Usefulness of a commercial equine IgG 
test and serum protein concentration as indicators of failure of transfer of passive immunity in hospitalized foals. J. Vet. Intern. Med. 20: 382-387. [Medline] [CrossRef]

35. Morris, D. D., Meirs, D. A. and Merryman, G. S. 1985. Passive transfer failure in horses: incidence and causative factors on a breeding farm. Am. J. Vet. Res. 46: 2294-2299. [Medline]

36. Pearson, R. C., Hallowell, A. L., Bayly, W. M., Torbeck, R. L. and Perryman, L. E. 1984. Times of appearance and disappearance of colostral IgG in the mare. Am. J. Vet. Res. 45: 186-190. [Medline]

37. Perryman, L. E. and McGuire, T. C. 1980. Evaluation for immune system failures in horses and ponies. J. Am. Vet. Med. Assoc. 176: 1374-1377. [Medline]

38. Pusterla, N., Pusterla, J. B., Spier, S. J., Puget, B. and Watson, J. L. 2002. Evaluation of the SNAP foal IgG test for the semiquantitative measurement of immunoglobulin $\mathrm{G}$ in foals. Vet. Rec. 151: 258-260. [Medline] [CrossRef]

39. Raidal, S. L. 1996. The incidence and consequences of failure of passive transfer of immunity on a thoroughbred breeding farm. Aust. Vet. J. 73: 201-206. [Medline] [CrossRef]

40. Robinson, J. A., Allen, G. K., Green, E. M., Fales, W. H., Loch, W. E. and Wilkerson, C. G. 1993. A prospective study of septicaemia in colostrum-deprived foals. Equine Vet. J. 25: 214-219. [Medline] [CrossRef]

41. Rumbaugh, G. E., Ardans, A. A., Ginno, D. and Trommershausen-Smith, A. 1978. Measurement of neonatal equine immuno- globulins for assessment of colostral immunoglobulin transfer: comparison of single radial immunodiffusion with the zinc sulfate turbidity test, serum electrophoresis, refractometry for total serum protein, and the sodium sulfite precipitation test. $J$. Am. Vet. Med. Assoc. 172: 321-325. [Medline]

42. Sellon, D. C. 2000. Secondary immunodeficiencies of horses. Vet. Clin. North Am. Equine Pract. 16: 117-130. [Medline]

43. Steven, D. H. and Samuel, C. A. 1975. Anatomy of the placental barrier in the mare. J. Reprod. Fertil. Suppl. 579-582. [Medline]

44. Stoneham, S. J., Digby, N. J. and Ricketts, S. W. 1991. Failure of passive transfer of colostral immunity in the foal: incidence, and the effect of stud management and plasma transfusions. Vet. Rec. 128: 416-419. [Medline] [CrossRef]

45. Tyler, J. W., Hancock, D. D., Parish, S. M., Rea, D. E., Besser, T. E., Sanders, S. G. and Wilson, L. K. 1996. Evaluation of 3 assays for failure of passive transfer in calves. J. Vet. Intern. Med. 10: 304-307. [Medline] [CrossRef]

46. Tyler-McGowan, C. M., Hodgson, J. L. and Hodgson, D. R. 1997. Failure of passive transfer in foals: incidence and outcome on four studs in New South Wales. Aust. Vet. J. 75: 56-59. [Medline] [CrossRef]

47. Waelchli, R. O., Hassig, M., Eggenberger, E. and Nussbaumer, M. 1990. Relationships of total protein, specific gravity, viscosity, refractive index and latex agglutination to immunoglobulin G concentration in mare colostrum. Equine Vet. J. 22: 39-42. [Medline] [CrossRef] 